\title{
Article
}

\section{HISTORIES, TRAUMAS, AND EMOTIONAL FORECLOSURE FROM MANHATTAN TO DUBLIN AND BACK}

\author{
Ian S. Miller ${ }^{1}$
}

\begin{abstract}
The present paper begins with the particulars of clinical practice in Ireland. Through clinical example, it examines the emotion of shame, widely paired with blame, as a socially acceptable admission of psychological functioning, both in exercising and in denying the communication of more profound feeling. As a necessary emotional outlet, shame authorizes aggressions both large and small. Shame demands that certain acts, often seemingly random and subjective, are to be judged disgraceful in others. Shame demands that someone, everyone, endures hurt, at least through social judgement. Passing through the armoring of shame as social defense, clinical examples focus on the defensive action of foreclosure as an interpersonal act of nihilation, reducing another to no-thing, while at the same time diminishing one's own sense of inadequacy. Discerning this clinical pattern, the author generalizes from practice in a particular place to similar observable patterns, both with different populations, and in different contexts.
\end{abstract}

KEY WORDS: social defense; Ireland; shame; foreclosure; cultural patterns

https://doi.org/10.1057/s11231-021-09282-2

\section{INTRODUCTION}

The present paper begins with my decision almost ten years ago, to relocate my practice of thirty years from New York City to Dublin, Ireland. Of course, much underlay this decision. The practice now contextualized by this act is connected not only with the elements and technical approaches characteristic of psychoanalytic psychotherapy learned from my more general training and clinical experience in the United States, but also my accommodation and integration with the pressures and influences upon

Ian S. Miller, Ph. D. is an Associate Editor of the American Journal of Psychoanalysis. Dr. Miller is a Member of the Irish Forum for Psychoanalytic Psychotherapy and a Chartered Psychologist in the Psychological Society of Ireland.

Address correspondence to: Ian S. Miller, Ph.D., Kilmainham Congregational Church, 62 Inchicore Rd., Dublin 8, Ireland. Email address: driansmiller@gmail.com. 
patients (and myself), of life in contemporary Ireland. Learning from experience has demanded accommodation of my interpersonal-relational practice to a setting where, as a newcomer to a place where this form of inquiry is largely undefined and unknown. When I arrived in Ireland, I frequently heard a disclaimer, itself a misquotation of Freud, that the Irish were impervious to psychoanalysis. As I now reflect on that urban myth, I realize that I have not heard it said by patients, in years. This is likely the result of our mutual recognition in recognizing the gravity of our work together, not only in addressing the general problems of mental health, but in affirming the vibrancy of life's strivings, daily. Significantly, after reading this essay, a New York colleague commented, "you say you're writing about a different place, but what's new here?", bluffly affirming the larger universal utility of the psychotherapeutic method. In the end, I moved to Ireland and everything was different; except the ideas animating the clinical field, generalized conceptions that travel the Atlantic well.

Three immediate and interactive challenges presented themselves. Unaware initially of their conjunction, these would define the gradient shaping my analytic practice. This paper's divisions correspond to these challenges. Section one, "Locating the Context of Psychotherapy" parallels my introduction of practice orientation to a community largely unacquainted with contemporary psychoanalytic thought (Miller, 2015, 2016; Miller \& Sweet, 2018). The second section, "Anxious Foreclosures in Daily Life" addresses particularities in my Irish practice from the perspective of strong and initially puzzling clinical registrations. The third section, "Three Clinical Vignettes" elaborates these clinical recognitions as more generalized dynamic patterns, useful in illuminating particular moments of clinical engagement within the course of one patient's psychotherapy. Finally, the fourth section, "Foreclosure, Trauma, Annihilation of the Other" returns from the plane of clinical observation toward more general conceptual linkages related to clinical foreclosure.

\section{LOCATING THE CONTEXT OF PSYCHOTHERAPY}

Writing at the dawn of psychoanalysis, Freud characterized the effects of the therapeutic encounter as a relationship of one mind upon another (Freud, 1890, p. 282). So expressed, the directionality of relational influence flows both ways. From my earliest days of practice, I have been mindful of the commonplace training wisdom that the therapist, perhaps differently from the patient, but with equal significance, must learn from clinical experience with each patient. 
Therapeutic mutuality necessarily involves both the internal and external worlds of clinician and patient. In this sense, both therapist and patient act in the roles of more or less inquiring psychologists, registering affective and ideational currents in a back-and-forth between Self and Other. Since William James' observations in Principles of Psychology (1890), the risk of distortion within this relationship, compounding earlier distortions, oblivions, and fixities within the discrete psychologies of each participant individual, has been an operational caveat of dyadic inquiry. James called this problem, the "psychologist's fallacy" (James, 1890, p. 195). However, the very permeability of one individual's psychic activity to another's through the interpersonal field of psychotherapy also makes possible an empathic mutuality termed mitleid in German (Goetschel, 2003, p. 102), the compassionate resonance of suffering between individuals. It is this mutuality that Ferenczi later develops in contribution to the psychoanalytic field (Ferenczi, 1932; Haynal, 2018). Similarly, affirmation of mutuality underlies what is now termed witnessing in the therapeutic literature on trauma (Felman \& Laub, 1992; Ullman, 2006; Mucci, 2013, 2019; Gondar, 2017). Central to this activity is the "recognition and placement of suffering" (Margālît, 2002, p. 82) through which the denials necessary for psychic survival, including "blindness to the big picture", "reducing expectations" and "of submitting but also managing to manipulate, argue, conceal, anger, and plead" (Ullman, 2006, p. 185) become lessened in the context of therapeutic experience. Only through such action is the patient enabled to draw disowned experience into the personal realm. So it is too, that in the relationship fundamental to psychoanalytic psychotherapy, the therapist must be mindful of an asymmetry recognized by Foucault as a technology of power, through the patient's seeking of relief, itself in large part, dependent upon therapeutic presence (Foucault, 1988).

The goal of therapeutic intervention toward a greater clarity of individual thought relative to perception, feeling, imagination, and desire, leads to improved capability in the patient's actions within the non-therapeutic, external world (Bion, 1962). This is accomplished through the exercise of reflective thinking, itself tangled in the complicated experiences of clinical interaction. Initially, within therapy, this is facilitated by the therapist's 1) bearing or containing of fragmentary experience articulated and enacted by the patient; 2) reflecting from within it through the analyst's countertransferential experience; and 3) expressing it to the patient in the form of, "what you call X, I call Y" (Miller \& Sweet, 2018). The dominant representatives of the two binary spheres of this lived, clinical experience, rooted in 19th century thought- "insight" (Einsicht) and "experience" (Erlebnis)—are perhaps most clearly personified respectively in the writings of Sigmund Freud and Sandor Ferenczi. 
Shifting between conceptual thought and lived experience, the intrinsically psychological field of action occurs in the shared domain of the interpersonal relationship. Today, this negotiated field of interaction between patient and analyst subjectivities is referred to as thirdness (Benjamin, 2004; Green, 1975; Ogden, 1994; Stern, 2013). Both therapist and patient may participate, acknowledged or not, in a developing, shared conviction of purpose, borne by the value and regularity of the psychoanalytic method, its form as thought collective rising historically from Breuer and Freud in $19^{\text {th }}$ century Vienna (Bolognini, 2008). Their initial application of the Aristotelian concept of catharsis, was expanded from its familiar dramatic setting to the field of psychopathology through the transformative interpretive lens of philologist Jacob Bernays (2004). Psychoanalysis has evolved well beyond cathartic technique over the last 130 years through different cultural challenges and expressions across a charged collective of thought orthodoxy, heresy, and thought extension (Bergmann, 1999). This has resulted in a generational consolidation of what the psychoanalytic thought collective deems significant in its transitory "vernacular expressions" (Miller, 2016, p. 7). These represent not only the segregation and splitting off of some streams of thought, but also the elaboration of other thought streams through a process by which an idea (such as the Unconscious), once mooted as radical, eventually evolves into general use, is affirmed, and then is confirmed in clinical practice.

Cardinal to the utility of psychotherapy is the centrality of transformation or change within the patient's psychosocial fields, both within the here-andnow field of dyadic clinical engagement and reported within the multiple domains characterizing the patient's experiences (Shedler, 2010). The centrality of transformation has been articulated philosophically since ancient days when Heraclitus imagined experience as a river of continuous change. Later, Marcus Aurelius determined that the mind's disciplined selfdirected reason could triumph over the body's contrary and chaotic desires. Within the predetermination of developmental factors upon which body and mind depended, Lucretius hypothesized the relatively random action or "swerve" of atomistic material elements in continuous conflict and interaction within the voids of contained space (Greenblatt, 2011). Modern psychology itself would later emerge from moral philosophy as Baruch Spinoza cut the medieval bond between individual process and individualized heavenly provenance. His recognition that humans construct their imagined myths of powerful external gods to validate their self-serving human desires - an early literary description of what later psychoanalysis would call "projective identification" — and to privilege rationality as mind's executive, determining sequential thought and considered action (Fromm, 1964; Spinoza, 1677, pp. 25-26). Spinoza also recognized the functional 
difference between the mind's bodily substrate and the operations of mind itself, for which he posited five functional domains: perception, feeling, imagination, appetite, and the rational capacity for reflective thought. Freud extended Spinoza's idea of the mind's functional differences from the body through neurological application of Hughling Jackson's scientific observation of "concomitant dependency," (Grossman, 1992, footnote 2, p. 34.) wherein one operative system both depends upon and differs from its subordinate, formative systems. At roughly the same historical moment, psychologist John Dewey observed that stimulation at one end of the reflex arc varied in function and experience both from discrete moments of stimulus-response pairing and from behavioral outcomes at the arc's far end (1896). Today, these consonant recognitions are mirrored clinically in the notion of multiple interactive functional levels of psychological activity; themselves operative within therapeutic engagement and resonant within the analyst's movement between deep engagement with the patient and reflective intuition in countertransference (Civitarese, 2008; Waelder, 1930). The transformational ethos characterizing psychoanalytic inquiry, itself a transformation of Aristotle's distinction between recognition (anagnoresis) and the action contingent upon recognition (metabasis) (Mendelsohn, 2017, p. 243) is captured in Freud's depiction of the process of understanding as leading from "bewilderment'" to "illumination'" (Freud, 1905, p. 12)

The foregoing serves as background to my understanding of psychoanalysis both as a generative theoretical model and a series of speculative propositions, testable in clinical interaction, with changing affirmations of clinical utility and reliability generally recognized by professional consensus. It also corresponds to the way in which I have presented psychoanalysis to Irish colleagues (Miller, 2015; Miller, 2016; Miller \& Sweet, 2018).

\section{ANXIOUS FORECLOSURES IN DAILY LIFE}

My arrival in Ireland coincided with the traumatic crash of the "Celtic Tiger," the economic boom that had achieved much in leapfrogging the country from its predominantly agricultural past into late modernity. "We lost the run of ourselves," was a commonly heard expression, as taxi drivers lamented the loss of their properties in Romania, Portugal, and Spain, each connected to the other through a tangle of interconnected mortgages founded on belief in the limitless rise of property prices. The middle class reeled from onerous bank fees, still owed for mortgaged Irish property that had lost $50 \%$ of its recent value. Clinically, patients' self-diagnoses of depression, frequently including thoughts of suicide, were linked 
consciously to the economic implosion and dashed dreams of unlimited future possibility. The government, itself, had set up a unit called the "National Asset Management Agency" to preside over 31.8 billion Euros in bank loan losses (O'Halloran, 2017). Foreclosure was on everyone's mind.

The expression, "we lost the run of ourselves" seemed to correlate clinically with a term frequently employed by patients to describe their feelings, shame. Its meaning often difficult to penetrate in its complexity, I came to hear "shame" as a frequently locked gateway of foreclosure to multiple, painful, affective states and actions. I understood the word in its early modern psychological meaning as a diminished sense of self related to external punishment and blame. Spinoza described this internal condition as "sadness" on the same continuum between pleasure and pain as Freud's later "pleasure principle" (Freud, 1920). His observation was that this particular sadness rose from the omnipotent self-judgment that one is to be blamed (Spinoza, 1677, p. 86). Together with my patients, I observed that shame, blame, and sadness operated as an often-impermeable ideational triad, verbally signaling a damnation of despair elegantly expressed by Irish author Brian Friel (1980) in his play The Faith Healer, of patients who,

even though they told themselves they were here because of the remote possibility of a cure, knew in their hearts they had come not to be cured but for confirmation that they were incurable; not in hope but for the elimination of hope; for the removal of that final, impossible chance-that's why they cameto seal their anguish, for the content of finality (Friel, 1980, p. 8).

So final does this condition of shame become, that its doomed trajectory drives, as the playwright observes, to the elimination of hope within a culturally affirmed guarantee of foreclosure. Under this reading, the possibility that early and subsequent trauma might be recognized clinically through the twinned therapeutic actions of witnessing and exploration, often resounded for my patients as surprised disbelief. Similarly, the possibility that present situations evoking shame and failure might be understood and more productively worked through in the absence of additionally shameful pain, seemed extraordinary to my patients.

It was in the context of worry about the possible loss of his home, shameful to him, that I met "Patrick". He was a recently unemployed middle-aged man who, in time, alerted me to the active presence of deeply experienced trauma. Despite verbalization of his traumatic history, months into therapy, Patrick's intellectual awareness of this past experience had been always been constant, the background to ongoing life experience. It was not simply that trauma remained unspoken and disavowed, but rather that the nature of his situation had been considered so ubiquitous that it fell beneath significance both to Patrick and to others-precluding integration 
in the realm of conscious, personal subjectivity (Garon, 2004, 2012). Never having been marked as meaningful, so never addressed in repair, Patrick's personal experience had slipped beneath the horizon of emotional significance. Yet the fierce tenacity of this event had been in its enduring and corrosive presence as unformulated experience (Stern, 1987).

Late in therapy, Patrick would characterize his lifelong, conscious sense of shame as an inadequate, if socially acceptable marker of such trauma and its corrosive consequences. He would comment too, that this inadequacy felt cemented in place by the aggression and defensiveness often present in everyday conversation. For example, speaking about a work supervisor, Patrick observed that her reception and response to a question he had asked, the answer to which she did not know, acted powerfully to discourage his curiosity. Her answer was an off-putting, "what are you going on asking me that stupid question?"

Following Patrick's observation that his curiosity had been aggressively curtailed in this example, a particular instance of socially acceptable communicative style, I recognized the traumatic markers of reduced expectation and blindness to a bigger picture together with the demand for submission, all linked within a matrix of manipulation, argument, concealment, and anger (Ullman, 2006). Open to inquiry, Patrick suggested that at the simplest level, his colleague might be ashamed at not knowing the answer he sought. Further, she might feel demeaned by being placed in a situation that might reveal her ignorance. Still, the effect upon Patrick of this regularly communicated form of negation led to his cumulative sense of hopelessness and shame, as he considered the futility of mutually productive interpersonal communication.

Patrick's description of this general communicative pattern reminded me of themes I had encountered in modern Irish literature. It echoed the despair of Friel's Faith Healer (1980), with its drive toward the terrible certainty of emotional foreclosure. I had also tracked the literary portrayal of this pattern across multiple Beckett narratives, elaborated over a forty-year period. Beginning with a specific traumatic occurrence-a mother's fierce negation of her small son's naïve question - the effects of her coarse and annihilative response becomes the basis of the productive, repetitive, working through of this unbearable wound by the man who was once the boy, until arrival at his capacity to bear his experience, if not to understand it (Miller, 2017). Beckett's literary success-and therapeutic beacon-is in demonstrating the possibility of eventually transforming trauma's continuously present pain along the hard-won lines of the Kleinian "depressive position" (Klein, 1940). This literary process may be reflective of Beckett's own capacity to mobilize the psychoanalytic method, long after the formal conclusion of his personal treatment with the young W. R. Bion (Miller \& Souter, 2013). Through 
illustration of this process, central to the emotional well-being of his protagonist, Beckett's literary depiction signals hope for patients' similar experience, emergent in psychoanalytic psychotherapy (Miller, 2016; Miller, 2017; Miller \& Souter, 2013).

In the Beckett example, the original trauma was the shock of a mother's frustrated "fuck off" (Miller, 2015, p. 52) to her young son. Patrick's parallel situation was as clearly etched in his memory. He had been explaining to me as an outsider unaware of recent Irish history, that corporal punishment in Irish public schools had only been recognized as a criminal offense, twenty years earlier, in 1996. In this associative context, quietly reviewing his first week in primary school in the 1980s, he said, "the teacher beat the lad next to me for no reason, and I pissed my pants." Initially, Patrick attempted to disclaim the memory with the familiar, "sure, other people have had it much worse." Yet, he responded strongly to my own involuntary reaction in painful witness of this simple testimony. This responsive listening required no interpretation, only a painful bearing in mutual suffering. As if extended permission, Patrick burst into tears, long contained by him under strong cultural proscription but suddenly, acceptable for expression within the experience of psychotherapy's safety. Until that therapeutic moment, he had been, he told me, "meant to suck it up, to cop onto myself" rather than to reckon consciously with his experience.

Patrick's emotional recognition underlay a therapeutic turning point for him. He said that he had felt liberation from a life-long sense of cowardice and shame, and with a firm sense of determination, in time, located a new position that productively absorbed his interest. Learning from him, I became deeply mindful that the stories I heard anecdotally, the newspaper accounts I read, and the public exhumation of traumas long buried, operated actively in the context of my patients' current and historical experience. What appeared clinically as stoical endurance, shame or denial, often correlated with the events of current newspaper reportage: clerical sexual abuse; the wounds of sectarian war only recently stilled by the 1999 Good Friday Agreement; the institutionalization of children in brutal industrial schools and Magdalene Laundries; and together with only recently prohibited corporal punishment in educational facilities, specific familial stories of particularized abuse and neglect, often the effects of grinding poverty, alcoholism, and parents overwhelmed by the responsibilities of maintaining large families, under a proscription of effective family planning. Contraception had only become permissible in Ireland in 1985. The 1983 Eighth Amendment to the Irish Constitution, making the life of a woman legally equivalent to the life of her fertilized egg and so, affirming in civil law, a harsh theological view of abortion as murder, was overturned by referendum only recently, in 2018. 
The witnessing of traumatic experience and its legacies, together with piecing together its effect on the contemporary fabric of patients' lives, became a strong undercurrent in my work. Both my clinical experience with patients and self-reflection upon my own, private experiences of impaired self-esteem and blame, sensitized me not only to the wide range of possibilities endured in culturally-enacted trauma, but also to private domains both of shame and shame's tough negations, whether in foreclosed if damnable experience or as prideful triumph in overcoming a wounding, its eidetic marker verbalized by American author Stephen Crane (1993), long ago, as a red badge of courage. Researching the dynamics of Irish slagging, a competitive heightening of reciprocal derogation that operates to bind individuals within socially-acceptable levels of verbal aggression while maintaining intimate distance, I worried that my inquiry, disclosed to the professional world beyond Ireland, might be received shamefully, misunderstood, or dismissed. In this, I registered a cautionary intimation of future shame, so a motivation for its avoidance by saying nothing. This intuitive personal recognition, akin to clinical registrations of countertransference, became key to my findings (Miller, 2019).

Through critical reflection upon written works as cultural documents, I was able to isolate what, for me as a newcomer, seemed a harsh, if acceptable social pattern characterizing relationships of caring, pivoting on the utility of shame as the fulcrum of tolerably borne, painful emotion. In Ireland, I found myself chastised by patients for becoming demonstrably passionate about an issue. They called this "giving out;" and recommended to me as a newcomer or "blow-in," that I learn to suppress passionate expression, mindful of two common sensibilities: demand for the stoically individual bearing of shame together with harsh social evaluation of personal culpability in failure and blame.

Focused upon the dynamics of shame, including its defiant denial, I became mindful of patients' stories concerning difficulties between themselves and others, in interpersonal relations. Initially, I heard these almost as footnotes at the edge of their ostensibly, more pressing, issues. In time, I began to think of such patterning as foreclosure, similar psychologically to what we heard about more concretely in the sphere of property. In the latter physical case, property purchased with borrowed money is repossessed by lenders. In the former, psychological experience undergone by the individual becomes invalidated in social experience, sometimes traumatically. Holding one's experience within oneself, and the bearing of pejorative social judgment in silence, become the individual's shameful burden. Following the familiar shorthand of trauma, the route to foreclosure begins in negation, with experience going unacknowledged. It continues by being unspoken, descending into the active absence of unformulated 
experience. Finally, the trauma becomes unthinkable, while actively potent (Garon, 2004, 2012).

What seemed to work in its acceptable function as an adhesive plaster, suppressing foreclosed experience, was the cultural ubiquity of shame. While overt giving-out might be proscribed, the torments signaled by complaint, the "whining and moaning" of depicting one's lot or experience as "shameful," were socially recognizable and common. For example, respondents to Joe Duffy, a popular radio host fielding daily complaints regarding the hardships and unfairness of Irish life, would often begin, "it's a disgrace, Joe," with that locution itself humorously elevated as a contemporary Irish cultural trope in a popular recent publication (Macaree, 2013). The idea in this mockery is cautious awareness that complaints of disappointment and outrage both prevalent and maddeningly illogical, are assaults upon thinking, such as, "The dogs are all on the dole, Joe" or "They've employed horses in the hospitals, Joe" or "They're giving drugs to the ducks, Joe."

\section{THREE CLINICAL VIGNETTES}

Here are three clinical vignettes, situations initially presented at the margins of personal narrative by Patrick, and progressively productive of his further self-inquiry and reflection about his own and others' moments of foreclosed experience, which, for him, initially signaled the general emotional category of shame.

The first concerns a description, early in therapy, of his spontaneous gesture in presenting his wife, Mary, with a box of chocolates, meant to be indicative of his affection for her. Unable to find Mary's favorite brand at several stores visited on his route home to suburban Dublin, Patrick purchased another variety of candy. He noted his anxious intimation that the purchase might be unappreciated, knowing Mary's general range of response; and experience proved him right. Mary received Patrick's gift scornfully, with the rebuke, "You know I like ' $X$ ' chocolates, not these". Speaking these words to me, Patrick reported his own immediate suffusion of shame in having done wrong, before rapidly shifting his narrative interest to another subject. I however, remained stuck in imagining the situation he had just described. I inquired about his understanding of the interaction.

Patrick explained that the situation was always "black and white" with Mary: either a pass or a fail. He frequently found himself feeling a failure, heightened by her habitual instruction in how he might perform more successfully. Here, he told me, he felt that his intention had been obliterated. The entire incident came down, ludicrously, to one brand of 
chocolate rather than another; and the reason underlying the gift itself, went unseen.

As for feelings, Patrick seemed stumped. He began easily enough with the idea of shame. He said that his sense of self, of personal agency, had felt attacked. Going on, Patrick linked this with his own, habitual patterns of passivity and shame, related to the early history of trauma he had earlier disclosed in therapy. Then, as if freed in recognition of transference, he shifted to another emotional register. "I could care less about the damned candy," he said. "And I really don't think it is as important to her as she makes it out to be." Then, what was really going on between them?

The answer did not come immediately, but over weeks. Patrick considered that he was probably more comfortable with expressing his desire for emotional intimacy than Mary. Defensively, she had caused him to feel ashamed about the trivial, material, nature of his gift. Which thought signaled to Patrick that perhaps Mary had indeed, been aware immediately at some level, of his intention. Their joint enactment of shame had been orchestrated by them as if a pair, almost automatically, balancing injury to his self-esteem while stabilizing hers. Patrick hypothesized that Mary's negative judgment, while directed toward his emotional immobilization, had been defensive. What she sought to protect was her own fragility. Perhaps she herself had felt shamefully about her own incapacity to accept his symbolic gesture of love?

Rooted in Patrick's sense of conviction about its plausibility, this seemed a fair hypothesis. For the first time in therapy, Patrick delved beneath the cultural gateway of "shame," both as emotional allowance and as prohibited curiosity. He reckoned that the broad concept of shame signaled a sense of personal inadequacy in a way that was socially tolerable. Everyone could identify with it. Everyone could induce it in others. And, as in the back-and-forth of verbal slagging, while expressing pain, shame was oddly impersonal. It cauterized deeper psychological curiosity. The claim of shame was to foreclose deeper experience of the Self.

Conceptually, Patrick's reflection suggested that shame, widely paired with blame, serves as a socially acceptable gateway both in exercising and denying the action of more profound feeling. It serves both as an acceptable social admission of psychological function and as an empty verbal foreclosure, prohibiting further inquiry. Yet, as a necessary emotional outlet, shame also authorizes aggressions both large and small. Shame demands that certain acts, often seemingly random and subjective, are to be judged disgraceful in others. Shame demands that someone, everyone, endures hurt, at least through social judgment. Shame tolerates reciprocal intolerance and aggression, maintaining a relatively steady state of emotional discomfort and "optimal distance" between individuals (Bouvet, 
1958). Shame's continuous preoccupation with the judged infractions of everyday life obscures deeper traumatic hurts, personal, interpersonal, and societal. Patrick recognized that the ready emotional utility of shame functioned for him as a "cork in a bottle," trapping more lively, more difficult emotions in an anesthetized state. On their emergence, he would initially judge these emotions as shameful too; but working past shame, could reflect upon them and the other experiences, memories, and associations, attendant upon them, toward greater clarity about himself.

The second vignette follows the first by a few months. Patrick announced it uncertainly by saying that it seemed similar to the "chocolate" situation. What he knew was that the result of such interactions left him angry and exhausted; and if ashamed, the shame did not really concern what seemed to be an overt difficulty between himself and Mary; but, rather, the complete impossibility of genuine understanding or communicating such understanding between them. Instead, what each understood was their shared experience of uniquely separate personal hurts and aloneness.

Patrick said that he wanted to engage more harmoniously with Mary, to feel more comfortable with her. But, he reckoned that he might be able to do this better were he to understand what happened to him under the force of her rejection. However interactive the situation seemed to be with Mary, Patrick accurately located the therapeutic problem in himself. From this observational viewpoint, he suggested that the emotion he might have earlier identified in Mary as shame, was rather, a kind of unbearable frailty that he could not pinpoint; and it was her frailty, which she defensively projected outward toward him and which was further complicated by her habitual expressions of dissatisfaction, that bothered him.

The situation, as he outlined it, was straightforward. Patrick had easily responded to Mary's requests: first, that he light the sitting room stove; and next, that he empty the rubbish bins in the shed.

These were simple enough. But on returning from the shed, the oncekindled fire had become extinguished. Rather than agreement that a "good enough" (Winnicott, 1960) solution might be to try again, Mary's cutting words pointedly underlined Patrick's inadequacy. Feeling himself immobilized, he had felt deeply flawed, agreeing with her that he had failed.

What caught my attention was his description's telegraphic simplicity, reducing narrative to a condensation, as in dreams. Two associations immediately opened for me. The first was memory of a literary reference by Samuel Beckett in his radio play, All That Fall. It concerns the ongoing demands of everyday life, "the dusting, sweeping, airing, scrubbing, waxing, waning, mangling, drying, mowing, clipping, raking, rolling, scuffling, shoveling, grinding, tearing, pounding, and slamming" (Beckett, 1956 , p. 181). Next, came my own recent acquaintance with the art of fire- 
building as a necessary skill for weathering the damp, Irish winter. Coming from New York where over-heated apartments required the opening of windows rather than the stoking of stoves, I had been initially clumsy in mastering the steps necessary to achieve a roaring fire warming a drafty sitting room. I knew how easily initial efforts might fail; and had also learned through failure, to try again, harder.

I wondered out loud to Patrick whether the situation as outlined was not overly compressed. He didn't understand. I said, it occurred to me that the story he told seemed shorn of detail, as if the act of lighting a stove or of taking out the garbage was as simple as pressing a button. He laughed and then began to list the multiple steps I had come to recognize, too, as essential in igniting a stove: cleaning yesterday's ashes; selecting kindling and fire-starter; deciding on which of the several available fuels-coal, briquette, turf, wood-to use; and monitoring the kindled fire until the fuel ignites. In so doing, Patrick paused. He said, "I decided to take the garbage out before waiting for the fuel to catch fire."

Patrick had located his procedural error without shame or condemnation, but through the sequential cause-and-effect steps of rational thought (Bion, 1962). I wondered, though, from the way he'd told the story, whether both he and Mary had come to agree upon stove-lighting as a single, unitary act, consolidating what were many discrete actions into the desired end of a lighted fire? "Like the perfect box of chocolates?" he responded ironically, smiling.

Some time later, Patrick reported a similar request, again compounding stove lighting with another common household task. This time, he told me, he prefaced his work by saying to Mary that the stove-lighting would require a bit of time; and that he would get to the second task when he had satisfactorily accomplished the first. There was no congratulation on completion; but neither was there negative comment. What had shifted for Patrick in this testing of new, therapeutically tinctured thought through application in action, was his recognition that he had a voice. He could explain his intention clearly. The once-feared attack by authority, transferentially reminiscent of that long-passed moment in school when he'd "pissed" himself, did not need to mediate his relationship with Mary. Yes, she could be judgmental; but he was also able to hold his ground. What undid him, he reckoned, was not her criticism in present time, but that criticism's kindling of the historical criticisms that had undermined his sense of self-worth, stretching all the way back in time. Freed from the foreclosed burden of shame, he began to access these, and their clinical presentations, with relative ease. 
Patrick's final clinical example required my participation as listener only. He was proud that he had endured a situation and "trouble-shot" it himself. The story, as told, concerned a visit to his elderly mother. The weather had been terrible, with stormy winds and lashing rain. His mother had been relishing a meal of mashed potatoes and beans but had run out of potatoes. Patrick was recruited to purchase her spuds at the local shop.

However, much as with the earlier case of Mary's candy, Patrick noted that the store sold only five-kilogram bags of potatoes. Nothing smaller. He wrestled with himself, knowing his mother. He figured that she would find reason to complain, were he to bring her this large bag; but, alternatively, recognized that his intention was for her to have the dinner she desired. Patrick bought the potatoes and brought them home. Predictably, his mother "gave out," scolding him for the waste (whether of potatoes or of money, he did not know) in buying so many potatoes. Patrick knew that his rejoinder, that she'd have plenty left for the rest of the week, would not pass muster. He told me, smiling that, "her giving out just rolled off me."

Patrick said therapy had shown him how to think himself through foreclosed, shameful situations and to act accordingly. Before, attributed blame had always seemed to efface his sense of competence, whether in the immediacy of accusation or in evoking residual trauma. Sometimes, he reckoned that another's rejection merely reflected her own ability to think through a situation and to accept another person's imperfect help. But knowing that, Patrick said, he felt free to consult his feelings without the painfulness of shame and blame, recognizing his own and others' motivational intent, its correspondence to action, and the likely range of consequent outcomes. Patrick reflected that his mother rarely thanked anyone for anything; but then, he was thankful to himself for providing her with spuds and for returning from that visit with his own sense of personal integrity intact.

\section{FORECLOSURE, TRAUMA, AND ANNIHILATION OF THE OTHER}

Within the historical and interpersonally observed contexts of Irish experience, the markers of Patrick's successful clinical course combine well-known elements of psychoanalytic technique. The foundation of Patrick's conviction in the therapeutic process was laid through the action of mutuality between therapist and patient. In this, Patrick had registered the therapist's responsive, involuntary, shock on hearing of a traumatic incident that Patrick had long considered painful, if unremarkable. Such a moment of witnessing, while momentarily immobilizing the therapist's thinking, evoked gestural expression of deep feeling in the presence of the patient. 
This had resonated reciprocally for the patient in recognition of his own psychic functioning - which follows the same process as I described when accounting for movements of thought in the session. Through these reflections he can transform his blockages and inhibitions by recognizing what he does with the psychic forces that are within him, replacing previously destructive meanings belonging to the past with a freer circulation of affects and representations in the present, allowing both partners in the analytic setting to foresee the development of thinking (Green, 2000, p. 446).

Gently, if conventionally, the unpacking of subsequent narrative productions proceeded along the lines of Sullivanian "detailed inquiry" (Sullivan, 1955). These eventuated in Patrick's personal demonstration of clinical empirical "proof," as his own self-analysis detailed what, earlier, might have been painfully obscure, the incident of the "potato." Patrick's own self-analysis also demonstrated what Neville Symington (1986) recognizes as the concluding phase of psychoanalysis demonstrated by internalization and mobilization of the analytic method applied to new problems in daily life, following from the first two phases, the gestation of the presenting problem, and the clinical analytic encounter, itself (Symington, 1986). Conceptually, Patrick's therapeutic experience had proceeded from "bewilderment" to "illumination," the Freudian transformation of Aristotelian anagnoresis and metabasis (Freud, 1905, p. 12)

Yet, the residue of presentations like Patrick's remained with me. I became mindful of dyadic or social situations like that of the stove, where simple, joint reconnaissance of the behavioral field between individuals seemed to fail. An example is in the mystified nature of the potato purchase. Not initially, but through reflection over time, Patrick considered his mother's action as conveying intergenerationally, a family history of agricultural frugality and poverty, perhaps dating back to the famine of the mid- $19^{\text {th }}$ century. The pull of such unformulated and parataxic considerations operated effectively to complicate his mother's receptivity to an adequate response of her simple request. In the past, Patrick might have been befuddled. But, in recovering his own capacity to think through the implications of his actions (the decision to purchase the spuds, consequences be damned...), he was prepared to tolerate his mother's effective rejection. He now factored in the probability that his effort would be found wanting. His subsequent containment of this moment allowed him to reflect upon its root in the intergenerational transmission of trauma.

Initially hidden out of sight, as with the temporary difficulty of the stove, no glimmer of understanding had been available either to individual participants or consensually, together. And in the grim resolve of both participants, whether Patrick and Mary or Patrick and his mother, all had 
seemed lost. Blame, compounding so many earlier moments of blame and dread, was aggressively assigned. The ubiquitous Irish capability of craic, of ironic fun and humor in absorbing contradictions, wholly disappeared in the sudden terrible seriousness of each incident. And both parties knew it, though the terror was unformulated-just like that moment long ago when Patrick "pissed" himself at school. What remained was an immovable demand, harsh and judgmental, a sharp and perilous edge, in marked contrast to the psychoanalytic attitude of 'good enough' adequacy, itself the conceptual legacy of British analyst, D. W. Winnicott (1960). This blockage represented foreclosure with its destructive negation of thinking.

I also considered Patrick's observation that Mary's response had not mirrored her incapacity to address symbolic functioning, as had been my theoretical hunch under consideration of Ogden's "autistic contiguous" position, Balint's "basic fault," Green's "central phobic position" or Meltzer's "claustrum" (Miller \& Sweet, 2018) Instead, he pointed to the immediacy of her hair trigger reaction through which the projection of blame and its consequent heightening of the receiver's shame was only secondary, collateral damage from the perceived unspoken threat to Mary's vulnerability. This required that she understand the symbolic act. Patrick's presentation of candy had caught her unaware, in relation to her allowance for emotional response.

The effect of such immediate foreclosure is to annihilate some dimension of the Other. It is an act of nihilation, reducing him or her to no-thing while at the same time diminishing one's own sense of inadequacy (Miller, 2018). It is this process that leads to the final transit from recognition to dissociation, as allowance and sensitivity to the Other's distinctive differences and shared commonalities, passes into the ghostly unheimlich [uncanny] before disappearing from subjective registration (Freud, 1919). Elsewhere, I have written about this process in progression from the declarative "he is dead to me," which acknowledges peripheral awareness of an Other, to the prescriptive action of blanking, which illustrates our contemporary blunting of emotions in the civil and interpersonal spheres; and the ease with which the Other, another person (no matter what he or she represents or is purported to have done) is located as being beneath thought, diminished into a No-thing. Nothing (Miller, 2018).

Clinically, this process becomes knowable in the interpersonal field, through the mutual registration of shock. Both Ferenczi (1932) and Bion (1962) suggest that such catastrophic registration is where thinking begins. Ferenczi writes:

In moments of great need, when the psychic system proves to be incapable of an adequate response, or when these specific organs or functions (nervous and 
psychic) have been violently destroyed, then the primordial psychic powers are aroused, and it will be these forces that will seek to overcome the disruption. In such moments, when the psychic system fails, the organism begins to think (Ferenczi, 1932, p. 6).

Still, the quality of thought in this moment is not so clear. Clinical experience suggests that an emphasis should be placed not on thinking per se in terms of contingent thought, oriented toward action (Bion, 1962) but rather, in rudimentary associative representational ideas. Such ideas might be more intuitional impressions, still emotionally fused with the heat of violent destruction but differentiated from better-formed, "less lively perceptions, of which we are conscious, when we reflect" in moments of greater security and emotional safety (Hume, 1748, p. 13).

I close with another vignette from my Dublin practice, excerpted from the analysis of a senior teacher in the Dublin public schools. Listening to his description of engagement with a difficult colleague, my associative thought led to Christopher Bollas' observations on Melville's short story, "Bartleby, the Scrivener" (Bollas, 1974). I told the patient that the situation he described reminded me of the character, Bartleby, in Melville's story.

"Bartleby?" he questioned. "Melville never wrote anything consequential except Moby Dick."

"I didn't know that you were a Melville scholar", I observed.

"Never read anything by him", he said.

"Then how do you come by this opinion?"

"Everyone knows it," he said, as he quickly changed the subject.

Initially, I was left, mildly bemused; until I felt the finality of arrival at a dead end. I sensed that this negation, not only of my observation but also in the nature of facts, might be significant to our work. Yet, it was abundantly clear that my patient wanted to flee from inquiry, distancing himself from consideration of what we had both encountered.

"I wonder if we might put an asterisk next to this moment, and return to it, later?", I asked.

"Of course," he responded, relieved to be rid of the moment.

In the mutuality of this moment, he and I had jointly marked an occurrence witnessed by us both from our own individual perspectives. In his agreement that I might return with him to this moment at another time, there was further acknowledgment that it might be significant. And with this, there was the implicit recognition that I would hold its memory until another, more resonant moment, when greater clarity might be possible. For the moment, however, our interaction and his response would remain only 
as fragmentary experience. Later reference to it would require its registration in memory, contained and vocalized by the therapist until reciprocated by the patient. We would return and return to this "Bartleby" moment when the patient was better able to reflect. This moment would become a shared touchstone, a cornerstone of our work, indicative of the automatic, unthinking nature of foreclosure. Together, we would recognize that this bold and uninformed negation, had been offered in defensive preservation of this teacher's desire for certainty, against the terror of uncertainty.

The negation, foreclosure, and annihilation of thought, reflected in this report, are drawn from the specific patterns of local Irish presentation. Yet, my first literary acquaintance with such patterns, involving hard negation and annihilation of another's thinking, was signaled by Haydee Faimberg (1996) in her "Listening to Listening". Referencing an example brought by Freud in relation to wit, Faimberg recalls an incident from a 19th century Yiddish short story by Sholom Aleichem (Faimberg, 1996, p. 671). In the "Pot," the narrator is caught in a web of foreclosed and mutually contradictory statements by her antagonist. While appearing to justify the borrowing of a saucepan, each statement negates another statement, leading to the collapse of cause and effect thinking. Together with this negation of thought is a consistent harshness and degradation, not dissimilar from the reports of shaming by my contemporary Irish patients.

But then Gnessi (may she sink into the earth) once borrowed a pot from me, a brand-new pot, and then she goes and gives me back a crippled pot. So I said to her, "What kind of pot is this?" So she said, "It's your pot." So I said, "How come I get a crippled pot when I gave you a brand-new pot?" So she said, "Shut it. Don't yell like that, who needs your things? First of all, I gave you back a brand-new pot. Second, the pot I took from you was a crippled pot. And third, I never even took a pot from you. I have my own pot, so get off my back (Sholom Aleichem, 1979, p. 80).

Freud's inclusion of this story in his work on wit (1905) focuses on Eastern European Jewish culture of the late 19th century but illustrates clinical processes discernable in my contemporary Irish practice. This local pattern, once identified clinically, is as my New York colleague remarked, recognizable to practicing psychoanalysts, if in another practice location. As demonstrated in this example, psychoanalytic practice is a back-andforth oscillation between local particularities and the generality of dynamic patterns, serves in its commitment to the establishment of rational thinking upon parataxic irrationality, as a potent antidote to this condition, directed to individuals, case by case. Minimally, it expands the patient's experience in the intolerant foreclosure of curiosity under the demand that one's response is in perfect conformity with the Other's expectation. It achieves this through mutuality together with the therapeutic willingness to take the 
effects of trauma seriously; and to attempt rational understanding of the individual's experience of Self and Other through the intersubjective medium of the analytic dyad.

\section{CODA}

Sholom Aleichem's early example is paralleled in an ironic commentary on our globalized world by New York Times columnist, Paul Krugman. Observing panic at the growing spread of the 2020 coronavirus, Krugman would caustically write about governmental response in the United States:

So, here's the response of the Trump team and its allies to the coronavirus, at least so far: It's actually good for America. Also, it's a hoax perpetrated by the news media and the Democrats. Besides, it's no big deal, and people should buy stocks. Anyway, we'll get it all under control under the leadership of a man who doesn't believe in science (Krugman, 2020).

In an era increasingly inured to anti-thinking (Miller, 2018), the foreclosed response, sealed off from reason and armored against inquiry, emerges from literature and clinical practice into daily discourse. If the experience of encountering such powerful resistance to cause-and-effect thinking in clinical contact is indicative, such traumatized and traumatizing communication will challenge us all in the public sphere. Clinicians must be equal to this challenge.

\section{NOTE}

1. Ian S, Miller, Ph.D, is a clinical psychologist/psychoanalyst and writer, based in Dublin, Ireland. He is Associate Editor of the American Journal of Psychoanalysis and member of the Irish Forum of Psychoanalytic Psychotherapy. He is a Chartered Psychologist in the Psychological Society of Ireland. He is the author of the books, On Minding and Being Minded: Experiencing Bion and Beckett (Karnac, 2015), Defining Psychoanalysis: Achieving a Vernacular Expression (Karnac, 2016), Beckett and Bion: The (Im)patient Voice in Psychotherapy and Literature (with Kay Souter, Karnac, 2013), and On the Daily Work of Psychodynamic Psychotherapy (with Alistair, 2018). 


\section{REFERENCES}

Balint, M. (1968). The basic fault. London: Tavistock.

Beckett, S. (1956). All that fall. Samuel Beckett. The Grove centennial edition. Vol. III, dramatic works (pp. 155-188). New York: Grove Press. 2006.

Benjamin, J. (2004). Beyond doer and done to: An intersubjective view of thirdness. Psychoanalytic Quarterly, 73(1) 5-46.

Bergmann, M. (1999). The dynamics of the history of psychoanalysis: Anna Freud, Leo Rangell, and André Green. In G. Kohon (Ed.), The dead mother. The work of André Green (pp. 193-204). London: Routledge.

Bernays, J. (2004). On catharsis: From fundamentals of Aristotle's lost essay on the effects of tragedy' (1857). P. Rudnytsky (Trans.). American Imago, 61(3), $319-341$.

Bion, W. (1962). The psycho-analytic study of thinking. International Journal of Psychoanalysis, 43, 306-310.

Bollas, C. (1974). Melville's lost self: Bartleby. American Imago, 31(4), 401-411.

Bolognini, S. (2008). Secret passages. London: Routledge. 2011.

Bouvet, M. (1958). Technical variation and the concept of distance. International Journal of Psychoanalysis, 39, 211-221.

Civitarese, G. (2008). Immersion versus interactivity and analytic field. International Journal of Psychoanalysis, 89(2), 279-298.

Crane, S. (1993). The red badge of courage. New York: Baronet.

Dewey, J. (1896). The reflex arc concept in psychology. Psychological Review, 3(4), $357-370$.

Faimberg, H. (1996). Listening to listening, International Journal of Psychoanalysis, $77,667-677$.

Felman, S. \& Laub, D. (1992). Testimony. Crises of witnessing in literature, psychoanalysis, and history. London: Routledge.

Ferenczi, S. (1932). The clinical diary of Sándor Ferenczi. J. Dupont (Ed.), M. Balint \& N.Z. Jackson (Trans.). Cambridge, Mass. \& London: Harvard University Press. 1988.

Foucault, M. (1988). In L. Martin, H. Gutman, and P. Hutton (Eds.), Technologies of the self. A Seminar with Michel Foucault. London: Tavistock.

Freud, S. (1890). Psychical (or mental) treatment. Standard Edition, Vol. 7, (pp. 281-302). London: Hogarth

Freud, S. (1905). Jokes and their relation to the unconscious. Standard Edition, Vol. 8, (pp. 9-236). London: Hogarth.

Freud, S. (1918). Lines of advance in psycho-analytic therapy. Standard Edition, Vol. 17, (pp.157-168). London: Hogarth.

Freud, S. (1919). The 'uncanny.' Standard Edition, Vol. 17, (pp. 217-252). London: Hogarth.

Freud, S. (1920). Beyond the pleasure principle. Standard Edition, Vol. 18, (pp. 1-64). London: Hogarth.

Friel, B. (1980). Faith healer. London: Faber \& Faber.

Fromm, E. (1964). Humanism and psychoanalysis. Contemporary Psychoanalysis, $1(1), 69-79$.

Garon, J. (2004). Skeletons in the closet. International Forum of Psychoanalysis, 13(1-2), 84-92.

Garon, J. (2012). From disavowal and murder to liberty. American Journal of Psychoanalysis, 72(1), 33-45. 
Goetschel, W. (2003). Spinoza's modernity. Mendelssohn, Lessing, and Heine. Madison: University of Wisconsin Press. 2004.

Gondar, J. (2017). Between psychoanalysis and testimonial space: The analyst as witness. American Journal of Psychoanalysis, 77, 52-63.

Green, A. (1975). The analyst, symbolization, and absence in the analytic setting (on changes in analytic practice and analytic experience)-in memory of D. W. Winnicott. International Journal of Psychoanalysis, 56, 1-22.

Green, A. (2000). The central phobic position. A new formulation of the free association method. International Journal of Psychoanalysis, 81(3), 429-451.

Greenblatt, S. (2011). The swerve. How the world became modern. New York: W. W. Norton.

Grossman, W. I. (1992). Hierarchies, boundaries, and representation in a Freudian model of mental organization. International Journal of Psychoanalysis, 40, $27-62$.

Haynal, A. (2018). Mutuality. American Journal of Psychoanalysis, 78, 342-349.

Hume, D. (1748). An enquiry concerning human understanding. Oxford: Oxford World Classics. 2007.

James, W. (1890). The principles of psychology. Vols.1-2. Cambridge, Mass: Harvard University Press. 1981.

Klein, M. (1940). Mourning and its relation to depressive states. In: Love, guilt and reparation and other works, 1921-1945 (pp. 344-369). New York, N.Y.: Free Press. 1975.

Krugman, P. (2020, Feb. 27). When a pandemic meets a personality cult. New York Times. Retrieved from: https://www.nytimes.com/2020/02/27/opinion/ coronavirus-trump.html?action=click\&module=Opinion \&pgtype=Homepage

Macaree, F. (2013). It's a disgrace, Joe. Retrieved from: https://www.macarie.ie

Margālît, A. (2002). The ethics of memory. Cambridge, MA: Harvard University Press.

Mendelsohn, D. (2017). An odyssey. A father, a son and an epic. London: William Collins

Miller, I. S. (2015). On minding and being minded. Experiencing Bion and Beckett. London: Karnac.

Miller, I. S. (2016). Defining psychoanalysis: Achieving a vernacular expression. London: Karnac.

Miller, I. S. (2017). Reading Beckett in the context of psychoanalysis: A literary bridge between one person and two-person psychology. British Journal of Psychotherapy, 33(4), 456-469.

Miller, I. S. (2018). Reading Willie Wonka in the era of anti-thinking. American Journal of Psychoanalysis, 78(2), 113-125.

Miller, I. S. (2019). Between bold cautions and emotional exposure: A fairytale of New York from Dublin. Psychoanalysis, Culture, and Society. Retrieved from: https://doi.org/10.1057/s41282-019-00136-6

Miller, I. S. \& Souter, K. (2013). Beckett and Bion: The (im)patient voice in psychotherapy and literature. London: Karnac.

Miller, I. S. \& Sweet, A. (2018). On the daily work of psychodynamic psychotherapy. London: Routledge.

Mucci, C. (2013). Beyond individual and collective trauma. Intergenerational transmission, psychoanalytic treatment, and the dynamics of forgiveness. London: Karnac. 
Mucci, C. (2019). Traumatization through human agency: "Embodied witnessing" is essential in the treatment of survivors. American Journal of Psychoanalysis, 79, 540-554.

O'Halloran, B. (2017, Sep. 15). Q \& A: What is the National Asset Management Agency? The Irish Times. Retrieved from: https://www.irishtimes.com/business/ economy/q-a-what-is-the-national-asset-management-agency-1.3222265

Ogden, T. H. (1994). The analytic third: Working with intersubjective clinical facts. International Journal of Psychoanalysis, 75, 3-19.

Shedler, J. (2010). The efficacy of psychodynamic psychotherapy. The American Psychologist, 65(2), 98-109.

Sholem Aleichem (1901). The Pot. In I. Howe and R. Wisse (Eds.), The best of Sholem Aleichem. (pp. 71-81). Washington DC: New Republic Books. 1979.

Spinoza, B. (1677). Ethics. (E. Curley, Trans.). London: Penguin Classics. 1994.

Stern, D. B. (1987). Unformulated experience and transference. Contemporary Psychoanalysis, 23, 484-490.

Stern, D. B. (2013). Field theory in psychoanalysis, Part 2: Bionian field theory and contemporary interpersonal/relational psychoanalysis. Psychoanalytic Dialogues, 23(6), 630-645.

Sullivan, H. S. (1955). The psychiatric interview. London: Tavistock Publications, Ltd.

Symington, N. (1986). The analytic experience. London: Free Association. New York: St. Martin's Press.

Ullman, C. (2006). Bearing witness: Across the barriers in society and the clinic. Psychoanalytic Dialogues, 16(2), 181-189.

Waelder, R. (1930). The principle of multiple function: Observations on overdetermination. [Published in German, 1930] Reprinted in 2007: Psychoanalytic Quarterly, 76(1), 75-92.

Winnicott, D. W. (1960). Ego distortion in terms of true and false self. In: Maturational processes and the facilitating environment. New York: International Universities Press.

Publisher's Note Springer Nature remains neutral with regard to jurisdictional claims in published maps and institutional affiliations. 